\title{
The Morphometry of the Angle of Mandible and its Correlation with Age and Sex in the eThekwini Metropolitan Region: A Panoramic Study
}

\author{
Morfometría del Angulo de la Mandíbula y su Correlación con Edad y \\ Sexo en la Región Metropolitana eThekwini: Un Estudio Panorámico
}

\author{
S. Pillay'; S. Ishwarkumar'; B.Z. De Gama ${ }^{1} \&$ P. Pillay ${ }^{1}$
}

PILLAY, S.; ISHWARKUMAR, S.; DE GAMA, B. Z. \& PILLAY, P. The morphometry of the angle of mandible and its correlation with age and sex in the eThekwini metropolitan region: A panoramic study. Int. J. Morphol., 35(2):661-666, 2017.

SUMMARY: The angle of mandible is formed by the tangent line joining the posterior margin of the ramus and the base of the mandible. The angle of mandible has population-specific characteristics therefore; it is imperative to the field of forensic anthropology for age and sex determination. Literary reports regarding the use of the angle of mandible for age and sex determination vary, as some studies support it, while other studies have documented inefficiencies. Therefore, the aim of this investigation was to document the morphometry of the angle of mandible and to determine if a correlation between the angle of mandible, age and sex exists. Sixty four digital panoramic radiographs $(\mathrm{n}=128)$ of individuals between 16-30 years were morphometrically analysed using the Dicom Digital Imaging Software. The data was captured and analysed using the Statistical Package for Social Science (SPSS version 23.0). Despite females having a greater angle of mandible than males, no statistically significant correlation was found between the size of the angle of mandible and sex ( $\mathrm{p}=0.088)$. The angle of mandible was observed to decrease with advancement of age, however only the 16-19 year age cohort displayed a statistically significant correlation with the size of the angle of mandible $(\mathrm{p}=0.006)$. Therefore, this study concluded that the angle of mandible may not be a useful indicator of sex, but may be a reliable indicator of age for individuals between 16-19 years in the eThekwini Metropolitan region.

KEY WORDS: Angle of mandible; Age; Sex; Mandible; Morphometry.

\section{INTRODUCTION}

The mandible is the second most durable bone of the body and is the most resilient in unfavourable conditions (Oettle et al., 2009). The angle of mandible is formed by the tangent lines of the posterior border of the ramus and the base of the mandible (Drake et al., 2010; Leversha et al., 2016). It is an important landmark of the mandible and is commonly used in forensic science for age, race and sex identification (Upadhyay et al., 2012). However, controversy exists with regard to the use of the angle of mandible in forensic science, specifically in age and sex determination (Upadhyay et al.).

The literature revealed that the angle of mandible may be an accurate cephalometric tool for population-specific age and sex identification (Singh et al., 2015). Conversely,
Oettlé et al. and Upadhyay et al. reported the angle of mandible to be an inefficient tool for the determination of age and sex, since there are countless factors that influence its development, viz. diet, dentition and population-specific characteristics.

Furthermore, the literature reviewed has documented that the size of the angle of mandible decreased from birth to adulthood and increased from adulthood to old age (Schuenke et al., 2004; Lipski et al., 2013). On the contrary, Leversha et al. reported a steady increase in the size of the angle of mandible with advancement in age.

In South Africa, the crime rate is continuously increasing (Crime Stats, 2017) with 17805 individuals

${ }^{1}$ Clinical Anatomy School of Laboratory Medicine and Medical Sciences College of Health Sciences University of KwaZulu-Natal Westville Campus Private Bag X54001 Durban, South Africa. 
murdered in 2015, consequently resulting in a large quantity of unidentified bodies recovered each year (Franklin et al., 2008a). The use of standard anthropological measurements of the angle of mandible may play a significant role in identifying unknown remains (Kitai et al., 2013). Furthermore, there are a few studies conducted on the angle of mandible and none of which were previously reported in the eThekwini Metropolitan region.

Therefore, the aim of this study was to determine the morphometry of the angle of mandible and its correlation with age and sex (if any) in the eThekwini Metropolitan region.

\section{MATERIAL AND METHOD}

Sixty-five digital panoramic radiographs of a South African Black population aged between 16-30 years were measured using the MicroDicom Digital Viewer (091-win32). 34 males and 30 female radiographs were categorized into 3 intervals: 16-19 years old, 20-25 years old, and 26-30 years old. The radiographs were obtained from the Radiological data bank at Clinical Anatomy, University of KwaZulu-Natal (Westville campus). Ethical clearance was obtained (LMMSEC 002/16).
The selection criteria were:

\section{Inclusion criteria}

- Patients between the ages of 16-30 years that have no history of trauma, with a complete medical record and full dentition

\section{Exclusion criteria}

- Panoramic radiographs that are not clear, patients that had mandibular and facial surgery or fractures to the jaws, as well as patients with oligodentia, systematic diseases or metabolic bone diseases

Morphometric Analysis. The morphometric parameters utilized in this study were adapted from Leversha et al. and measured using the MicroDicom (091-win32) digital software:

- Ramus line (RL) was measured from the posterior border of the condylar process of the mandible, along the posterior margin of the ramus to the edge of the inferior margin of the ramus (Plate 1$)$.

- Mandibular line (ML) was the line drawn anteriorly along the inferior margin of the body of the mandible through the gnathion, which is the middle point on the base of the mandible in the sagittal plane (Plate 1).

- Angle of mandible (GA) was measured at the intersection of the RL and ML (Plate 1).

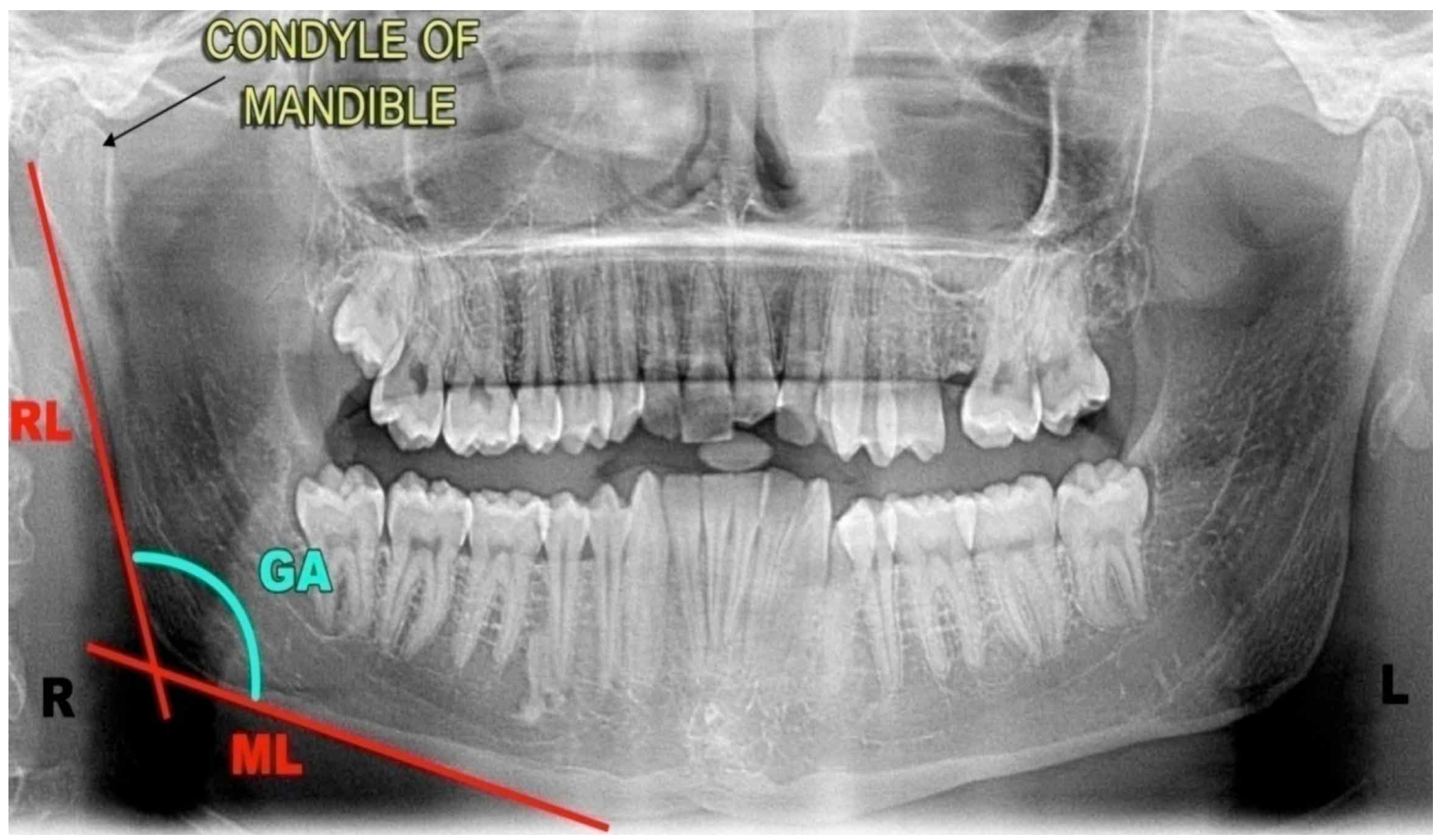

Fig. 1. Measurements of the angle of mandible on a panoramic radiograph x-ray of the mandible. Key: RL: Ramus line, ML: Mandibular line; GA: Angle of mandible; R: Right; L: Left 
Statistical Analysis. The data was captured and analyzed using the Statistical Package for Social Sciences (SPSS version 23.0) software. The Pearson Product Moment Correlation Coefficient Test was used to determine if a correlation exists between the angle of mandible and age, as well as the angle of mandible and sex. The Intra-Class Correlation Coefficient test was then employed to assess the inter-observer reliability (Cicchetti et al., 1994). A p-value of less than 0.05 was considered to be statistically significant.

\section{RESULTS}

Angle of mandible versus age. The size of the angle of mandible decreased with advancement in age from $121.63^{\circ}$ to $120.57^{\circ}$ (Table I). No statistical significance was observed between the size of the angle of mandible and age $(\mathrm{p}=0.487)$.

Age: 16-19 years. In the 16-19 year age cohort, the angle of mandible was slightly greater in females, with a mean angle of $121.81^{\circ}$, while in males it was recorded to be $121.37^{\circ}$. A statistically significant relationship between size of angle of mandible and the 16-19 year age cohort was recorded $(\mathrm{p}<0.006)$ (Table I).

Age: 20-25 years. In the 20-25 year age cohort, the size of the angle of mandible was $122.23^{\circ}$ and $119.92^{\circ}$ in females and males, respectively. No statistical significant difference was recorded between this age cohort and the size of angle of mandible ( $\mathrm{p}=0.096)$ (Table I).

Age: 26-30. The mean angle of mandible measured $123.16^{\circ}$ and $117.70^{\circ}$ in females and males, respectively. No statistically significant relationship between the size of the angle of mandible and 26-30 age cohort was recorded $(\mathrm{p}=0.194)$ (Table I).

Table I. Mean angle of mandible for males and females between 16-30 years of age $\left(\right.$ in $\left.^{\circ}\right)$.

\begin{tabular}{llll}
\hline Sex & \multicolumn{3}{c}{ Age Cohort (years) } \\
& $16-19$ & $20-25$ & $26-30$ \\
\hline Mean male angle of mandible & 121.81 & 119.92 & 117.71 \\
Mean female angle of mandible & 121.37 & 122.23 & 123.16 \\
Both & 121.63 & 120.87 & 120.57 \\
Value(angle of mandible v/s age) & $p=0.006$ & $p=0.096$ & $p=0.194$ \\
\hline
\end{tabular}

Table II: Mean angle of mandible for males and females (in ${ }^{\circ}$ ).

\begin{tabular}{lccc}
\hline Patients & Total sample size & Mean age (years) & Mean angle of mandible with SD (in ${ }^{\circ}$ ) \\
\hline Males & 34 & 22.85 & $119.65 \pm 7.88$ \\
Females & 30 & 23.75 & $122.40 \pm 4.52$ \\
\hline
\end{tabular}

Angle of mandible versus sex. The mean angle of mandible in males and females measured $120.94^{\circ}$. Females reported a greater angle of mandible than males, with a mean angle of mandible of $122.40^{\circ}$ and $119.65^{\circ}$, respectively (Table II). Despite these differences, no statistically significant difference was noted between the size of angle of mandible and $\operatorname{sex}(\mathrm{p}=0.088)$.

Reliability and validity. A second observer morphometrically analyzed 12 random digital panoramic radiographs using the MicroDicom (091-win32) digital software. The Intra-Class Correlation Coefficient test was then employed to assess the inter-observer reliability. A 0.989 significance for the mean angle of mandible between both observers was found, which donates excellent agreement $(\max =1)($ Cicchetti et al.). These findings are in agreement to Oettlé et al. who reported an Intra-Class Correlation Coefficient of 0.944 .

\section{DISCUSSION}

Angle of the mandible and age. In the present study, the mean angle the mandible was $121.03^{\circ}$, which correlated closely with the Lebanese, South African White, Jordanian and Australian population groups (Table III). However, the Indian population group reported the largest angle of mandible with a mean angle of $130.50^{\circ}$ (Table III). Furthermore, despite differences in the size of the angle of mandible in the different age cohorts, no correlation between the size of the angle of mandible and age were observed in this study $(\mathrm{p}=0.487)$. These results were in accordance with Oettlé et al. who investigated the South African Black population in the Tshwane metropolitan region. However, it differed from the study conducted by Leversha et al., who reported a statistical significance between age and the size of angle of mandible. However, when the size of the angle of mandible was correlated to each age cohorts, this study observed a statistically significant correlation between the 16-19 year age cohort and age $(\mathrm{p}<0.006)$. However, the present study was the first to document such a correlation. The aforementioned differences could be due to dietary differences, as well as local population-specific 
differences, however this was out of the scope of this study (Franklin et al., 2008b). Furthermore, these differences may be due to the sample size of this study.

This study also noted a trend between the size of the angle of mandible and age viz. the size of the angle of mandible decreased with advancement of age. This concurred with the findings of Upadhyay et al. in an Indian population. However, Al-Shamout et al. (2012) and Leversha et al. reported conflicting results, as they reported that the size of the angle of mandible increased with advancement of age in Jordanian and Australian populations, respectively.

Possible reasons for these differences may be due to craniometrical differences, which may have resulted from the evolutionary processes in different continents therefore this may contribute to population-specific differences (Oettlé et al.). Furthermore, genetic variation, climate, dietary habits and nutrition may also contribute to population-specific differences (Poongodi et al., 2015). South Africa is a multiracial country, therefore the sub-population groups within South Africa may have their own oestometric standards. This may account for the discrepancy that arises when the current study was compared to other South African literature (Franklin et al., 2008b).

Table III. Mean angle of mandible of different population groups (in ${ }^{\circ}$ ).

\begin{tabular}{lclll}
\hline Author & Year & Population & Age (years) & Mean GA \\
\hline $\begin{array}{l}\text { Ayoub } \text { et al. } \\
\text { Oettlé } \text { et al. }\end{array}$ & 2009 & Lebanese & $17-26$ & 121.38 \\
& 2009 & South African White & $\begin{array}{l}\mathrm{M}=38-91 \\
\mathrm{~F}=21-97\end{array}$ & 120.13 \\
Oettlé et al. & 2009 & South African Black & $\begin{array}{l}\mathrm{M}=23-98 \\
\mathrm{~F}=24-80\end{array}$ & 120.64 \\
& & & $15-30$ & 124.17 \\
Shahabi et al. & 2009 & Iranian & $20-29$ & 123.04 \\
Al-Shamout & 2012 & Jordanian & $17-35$ & 130.50 \\
Upadhyay et al. & 2012 & Indian & $18-29$ & 123.24 \\
Leversha et al. & 2016 & Australian & $16-30$ & 121.03 \\
Current study & 2016 & South African Black & & \\
\hline
\end{tabular}

Table IV. Angle of mandibles of males and female of different population groups $\left(\mathrm{in}^{\circ}\right)$.

\begin{tabular}{lclccr}
\hline Author & Year & Population & Age (years) & Male & Female \\
\hline De Villiers & 1968 & South African Black & - & 120.60 & 125.00 \\
Ayoub et al. & 2009 & Lebanese & $17-26$ & 121.76 & 121.00 \\
Shahabi et al. & 2009 & Iranian & $15-30$ & 123.68 & 124.39 \\
Oettlé et al. & 2009 & South African Black & M=23-98 & 120.11 & 121.17 \\
& & & F=24-80 & & \\
Oettlé et al. & 2009 & South African White & M=38-91 & 118.25 & 122.00 \\
& & & F=21-97 & & \\
Upadhyay et al. & 2012 & Indian & $17-35$ & 132.00 & 129.00 \\
Al-Shamout et al. & 2012 & Jordanian & $20-29$ & 123.23 & 122.84 \\
Leversha et al. & 2016 & Australian & $18-29$ & 121.53 & 124.94 \\
Current study & 2016 & South African & $16-30$ & 119.65 & 122.40 \\
\hline
\end{tabular}

Angle of the mandible and sex. In the present study, the female angle of mandible was observed to be greater than male. However, Ayoub et al. (2009) and Gamba et al. (2016) reported that males had a greater angle of mandible than their counterparts in Lebanese and Brazilian populations, respectively (Table IV). This study reported no statistically significant correlation between the angle of mandible and sex. This finding concurred with Oettlé et al. who conducted a study on the Black South African population in a Tshwane metropolitan area, as well as AlShamout et al. in a Jordanian population. However, Huumonen et al. (2010), in a Finnish population and Leversha et al. in an Australian population reported a significant correlation between the size of the angle of mandible and sex. These sex differences may be due to genetic variation, as the male mandible persists in growth after puberty in comparison to females (Franklin et al., 2008b). Furthermore, masseter force may also play a role in genetic differentiation, as males have a greater masseter force which reduces the size of the angle of mandible, thus resulting in a smaller angle of mandible in males than females (Ayoub et al.).

In addition, this study observed that the angle of mandible was $119.65^{\circ}$ in males. This concurred with the South African study conducted by Oettlé et al., who found a mean angle of mandible of $118.75^{\circ}$. However, Upadhyay et al. reported a mean angle in males of $132.0^{\circ}$ in the Indian population group, which was $12.35^{\circ}$ greater than the present study. In this study, the size of the angle of mandible in females was $122.40^{\circ}$, this concurred with the White South African population, who had mean angle of mandible of $122.48^{\circ}$ (Oettlé et al.). However, Upadhyay et al. reported a greater mean angle of mandible than the current study of $129.0^{\circ}$ for females in an Indian population (Table IV).

A possible explanation for this occurrence may be due to 
population-specific differences regarding the morphometric analysis of the angle of mandible (Poongodi et al.). In addition, different climate, nutrition and labour division may also contribute to population-specific differences regarding the size of angle of mandible (Poongodi et al.). This study recommends that future studies should include a larger sample size with a wider age range and to compare the size of the angle of mandible between the sub-population groups of South Africa.

\section{CONCLUSION}

The angle of mandible was found to decrease as age increased. A statistically significant correlation was only observed between the size of the angle of mandible and the 16-19 year age cohort $(\mathrm{p}<0.006)$. Although, other studies reported a significant difference between sex and the size of the angle of mandible, no statistically significant correlation between the afore-mentioned parameters was found in this study. Thus, the angle of mandible maybe an insufficient tool for sex identification in forensic science but may be useful in identifying human remains in the 16-19 year age cohort in the eThekwini Metropolitan region.

PILLAY, S.; ISHWARKUMAR, S.; DE GAMA, B. Z. \& PILLAY, P. Morfometría del ángulo goniaco y su correlación con edad y sexo en la región metropolitana eThekwini: Un estudio panorámico. Int. J. Morphol., 35(2):661-666, 2017.

RESUMEN. El ángulo de la mandíbula está formado por la línea tangente que une el margen posterior de la rama y la base de la mandíbula. El ángulo de la mandíbula tiene características específicas según la población; es imperativo en el área de la antropología forense para la determinación de la edad y género. Los informes literarios sobre el uso del ángulo de la mandíbula para la determinación de edad y género varían, según algunos estudios que lo apoyan, mientras que otros estudios han documentado ineficiencias. El objetivo de esta investigación fue documentar la morfometría del ángulo de la mandíbula y determinar si existe una correlación entre el ángulo de la mandíbula, la edad y el sexo. Se analizaron 64 radiografías panorámicas digitales $(n=128)$ de individuos entre 16-30 años morfométricamente utilizando el software Dicom Digital Imaging. Los datos fueron capturados y analizados utilizando el Paquete Estadístico para Ciencias Sociales (SPSS versión 23.0). A pesar de que las mujeres tenían un ángulo de la mandíbula mayor que los hombres, no se encontró una correlación estadísticamente significativa entre el tamaño del ángulo de la mandíbula y el sexo $(\mathrm{p}=0,088)$. Se observó que el ángulo de la mandíbula disminuyó con el avance de la edad, y solamente la cohorte de edades de 16-19 años mostró una correlación estadísticamente significativa con el tamaño del ángulo de la man- díbula $(\mathrm{p}=0,006)$. Por lo tanto, este estudio concluyó que el ángulo de la mandíbula puede no ser un indicador útil de sexo, pero puede ser un indicador confiable de edad para individuos entre 1619 años en la región metropolitana de eThekwini.

PALABRAS CLAVE: Ángula de la mandíbula; Edad; Sexo; Mandíbula; Morfometría.

\section{REFERENCES}

Al-Shamout, R.; Ammoush, M.; Alrbata, R. \& Al-Habahbah, A. Age and sex differences in gonial angle, ramus height and bigonial width in dentate subjects. Pak. Oral Dent. J., 32(1):817, 2012.

Ayoub, F.; Rizk, A.; Yehya, M.; Cassia, A.; Chartouni, S.; Atiyeh, F. \& Majzoub, Z. Sexual dimorphism of mandibular angle in a Lebanese sample. J. Forensic Leg. Med., 16(3):121-4, 2009.

Cicchetti, D. V. Guidelines, criteria, and rules of thumb for evaluating normed and standardized assessment instruments in psychology. Psychol. Assess., 6(4):284-90, 1994.

Crime Stats. Web Site. 2017. Available from: www.crimestatssa.com

de Villiers, H. Sexual dimorphism of the skull of the South African Bantu-speaking Negro. S. Afr. J. Sci., 64:118-24, 1968.

Drake, R. L.; Vogl, W. \& Mitchell, A. W. M. Gray's Anatomy for Students. $2^{\text {nd }}$ ed. Philadelphia, Churchill Livingstone/Elsevier, 2010. pp.814-7.

Franklin, D.; O'Higgins, P. \& Oxnard, C. E. Sexual dimorphism in the mandible of indigenous South Africans: a geometric morphometric approach. S. Afr. J. Sci., 104(3-4):101-6, 2008a.

Franklin, D.; O’Higgins, P.; Oxnard, C. E. \& Dadour, I. Discriminant function sexing of the mandible of indigenous South Africans. Forensic Sci. Int., 179(1):84.e1-5, 2008b.

Gamba, T. de O.; Alves, M. C. \& Haiter-Neto, F. Mandibular sexual dimorphism analysis in CBCT scans. J. Forensic Leg. Med., 38:106-10, 2016.

Huumonen, S.; Sipilä, K.; Haikola, B.; Tapio, M.; Söderholm, A. L.; Remes-Lyly, T.; Oikarinen, K. \& Raustia, A. M. Influence of edentulousness on gonial angle, ramus and condylar height. J. Oral Rehabil., 37(1):34-8, 2010.

Kitai, N.; Mukai, Y.; Murabayashi, M.; Kawabata, A.; Washino, K.; Matsuoka, M.; Shimizu, I. \& Katsumata, A. Measurement accuracy with a new dental panoramic radiographic technique based on tomosynthesis. Angle Orthod., 83(1):117-26, 2013.

Leversha, J.; McKeough, G.; Myrteza, A.; Skjellrup-Wakefiled, H.; Welsh, J. \& Sholapurkar, A. Age and sex correlation of gonial angle, ramus height and bigonial width in dentate subjects in a dental school in Far North Queensland. J. Clin. Exp. Dent., 8(1):e49-e54, 2016.

Lipski, M.; Tomaszewska, I. M.; Lipska, W.; Lis, G. J. \& Tomaszewski, K. A. The mandible and its foramen: anatomy, anthropology, embryology and resulting clinical implications. Folia Morphol. (Warsz.), 72(4):285-92, 2013.

Oettlé, A. C.; Becker, P. J.; de Villiers, E. \& Steyn, M. The influence of age, sex, population group, and dentition on the mandibular 
PILLAY, S.; ISHWARKUMAR, S.; DE GAMA, B. Z. \& PILLAY, P. The morphometry of the angle of mandible and its correlation with age and sex in the eThekwini metropolitan region: A panoramic study. Int. J. Morphol., 35(2):661-666, 2017.

angle as measured on a South African sample. Am. J. Phys. Anthropol., 139(4):505-11, 2009.

Poongodi, V.; Kanmani, R.; Anandi, M. S.; Krithika, C. L.; Kannan, A. \& Raghuram, P. H. Prediction of age and sex using digital radiographic method: A retrospective study. J. Pharm. Bioallied Sci., 7(Suppl. 2):S504-8, 2015.

Shahabi, M.; Ramazanzadeh, B. \& Mokhber, N. Comparison between the external gonial angle in panoramic radiographs and lateral cephalograms of adult patients with Class I malocclusion. J. Oral Sci., 51(3):425-9, 2009.

Singh, S.; Mishra, S. R.; Kumar, P.; Sinha, P.; Sushobhana; Passey, J. \& Singh, R. Location of mandibular foramen in correlation with the gonial angle in indian population: A morphometric study for surgical practices. Int. J. Anat. Res., 3(3):1345-50, 2015.

Upadhyay, R. M.; Upadhyay, J.; Agrawal, P. \& Rao, N. N. Analysis of gonial angle in relation to age, sex, and dentition status by radiological and anthropometric methods. J. Forensic Dent. Sci., 4(1):29-33, 2012.

\author{
Corresponding author: \\ Mrs P. Pillay \\ Clinical Anatomy \\ School of Laboratory Medicine and Medical Sciences \\ College of Health Sciences \\ University of KwaZulu-Natal \\ Westville Campus \\ Private Bag X54001 \\ Durban 4000 \\ SOUTH AFRICA
}

E-mail:soobramoneypa@ukzn.ac.za

Received: 23-12-2016

Accepted: 20-03-2017 